\title{
The Translation Repressor 4E-BP2 Is Critical for eIF4F Complex Formation, Synaptic Plasticity, and Memory in the Hippocampus
}

\author{
Jessica L. Banko, ${ }^{1 \star}$ Francis Poulin, ${ }^{3 *}$ Lingfei Hou, ${ }^{1}$ Christine T. DeMaria,${ }^{3}$ Nahum Sonenberg,${ }^{3 *}$ and Eric Klann ${ }^{1,2 *}$ \\ Departments of ${ }^{1}$ Molecular Physiology and Biophysics and ${ }^{2}$ Neuroscience, Baylor College of Medicine, Houston, Texas 77030, and ${ }^{3}$ Department of \\ Biochemistry, McGill University, Montreal, Quebec, Canada H3G 1Y6
}

\begin{abstract}
Long-lasting synaptic plasticity and memory requires mRNA translation, yet little is known as to how this process is regulated. To explore the role that the translation repressor 4E-BP2 plays in hippocampal long-term potentiation (LTP) and learning and memory, we examined 4E-BP2 knock-out mice. Interestingly, genetic elimination of 4E-BP2 converted early-phase LTP to late-phase LTP (L-LTP) in the Schaffer collateral pathway, likely as a result of increased eIF4F complex formation and translation initiation. A critical limit for activityinduced translation was revealed in the 4E-BP2 knock-out mice because L-LTP elicited by traditional stimulation paradigms was obstructed. Moreover, the 4E-BP2 knock-out mice also exhibited impaired spatial learning and memory and conditioned fear-associative memory deficits. These results suggest a crucial role for proper regulation of the eIF4F complex by 4E-BP2 during LTP and learning and memory in the mouse hippocampus.
\end{abstract}

Key words: LTP; protein synthesis; hippocampus; Morris water maze; learning and memory; fear conditioning

\section{Introduction}

Several forms of long-term synaptic plasticity and long-term memory require new macromolecular synthesis, whereas shortterm synaptic plasticity and short-term memory do not. Studies of mice with genetically altered transcription machinery have revealed significant insights concerning the regulation of mRNA synthesis during long-lasting synaptic plasticity and long-term memory (Barco et al., 2002; Chen et al., 2003); however, regulation of transcription is only one route of manipulating gene expression. Regulation of protein synthesis is another route and is the ultimate step in the control of gene expression, enabling cells to regulate protein production without altering mRNA synthesis or transport. Thus, it is necessary to examine the regulation of protein synthesis to gain a more complete understanding of the regulation of gene expression during long-term synaptic plasticity and long-term memory.

Protein synthesis is regulated primarily at the level of mRNA translation initiation (for review, see Dever, 2002). The ratelimiting event is recruitment of the $43 \mathrm{~S}$ ribosome to the mRNA. A

\footnotetext{
Received June 14, 2005; revised Aug. 25, 2005; accepted Aug. 30, 2005.

This work was supported by National Institutes of Health (NIH) Grants NS34007 and NS47384 (E.K.), the FRAXA Research Foundation (E.K.), NIH Training Grant T32 HL07676 (J.L.B.), NIH Fellowship F32 CA74494-01A1 (C.T.D.), a doctoral award from the Canadian Institutes of Health Research (CIHR) (F.P.), and grants from the (IHR and the Howard Hughes Medical Institute (HHMI) (N.S.). N.S. is a Distinguished Investigator of the CIHR and an HHMI International Scholar. We thank Caterina Hernendez, Jonathan Levenson, Colin Lister, Annie Sylvestre, Kyoko Tsukiyama-Kohara, and Edwin Weeber for providing reagents, excellent technical assistance, and insightful conversations.

*J.L.B., F.P., N.S., and E.K. contributed equally to this work.

Correspondence should be addressed to Dr. Eric Klann at the above address. E-mail: eklann@bcm.tmc.edu. DOl:10.1523/JNEUROSCI.2423-05.2005

Copyright $\odot 2005$ Society for Neuroscience $\quad$ 0270-6474/05/259581-10\$15.00/0
}

critical step in this process is the binding of the eukaryotic initiation factor $4 \mathrm{E}$ (eIF4E) as part of a protein complex, eIF4F, to the cap structure at the mRNA $5^{\prime}$ terminus (Gingras et al., 1999). eIF4E is regulated post-translationally by two mechanisms, sequestration and direct phosphorylation. eIF4E is sequestered by one of three related inhibitory binding proteins (4E-BPs) (Pause et al., 1994; Poulin et al., 1998). The 4E-BPs prohibit translation by hindering eIF4F complex assembly via occlusion of the eIF4G binding domain on eIF4E (Haghighat et al., 1995; Mader et al., 1995). Activation of a rapamycin-sensitive signaling pathway results in the hyperphosphorylation of 4E-BP and disruption of the 4E-BP-eIF4E complex (Beretta et al., 1996; Lin and Lawrence, 1996; Gingras and Sonenberg, 1997; Gingras et al., 1998). Replacement of 4E-BP with eIF4G leads to formation of the eIF4F complex and promotes translation initiation. eIF4F complexassociated eIF4E is phosphorylated by the kinase Mnk1 (Wang et al., 1998; Waskiewicz et al., 1999). Phosphorylation reduces the affinity of eIF4E for the cap (Niedzwiecka et al., 2002; Scheper et al., 2002; Zuberek et al., 2003).

Previous studies using genetic mutations or pharmacological agents that target kinases with substrates that include, but certainly are not limited to, translation factors suggested that increased phosphorylation of translation factors, including 4E-BP and eIF4E, occurs during long-term potentiation (LTP) and memory formation (Tang et al., 2002; Kelleher et al., 2004). However, the specific contributions of either 4E-BP or eIF4E to either LTP or memory formation have yet to be examined. We have begun to investigate this issue by examining hippocampal LTP and hippocampus-dependent memory in a mutant mouse generated to lack the eIF4E regulatory protein preferentially expressed in the brain, 4E-BP2. Our analyses disclosed that 4E-BP2 
knock-out mice have upregulated eIF4F complex formation, altered hippocampal LTP, and hippocampus-dependent memory deficits. The results of our investigations delineate an important function for 4E-BP2 in the regulation of eIF4F complex formation as one of the translational events underlying LTP and memory.

\section{Materials and Methods}

Homologous recombination. The mouse Eif4ebp2 gene was obtained by screening a $\lambda$ FixII 129/SvJ mouse genomic library (Tsukiyama-Kohara et al., 2001). The targeting vector consisted of a $4.9 \mathrm{~kb} \mathrm{XbaI} \mathrm{Eif4ebp2}$ genomic fragment upstream of exon 2, a pTK-Neo cassette (pMC1neo; Stratagene, La Jolla, CA), and a $1.2 \mathrm{~kb}$ AflIII-BclI Eif4ebp2 genomic fragment downstream of exon 2. Electroporation of the linearized vector (NotI) into 129/Sv embryonic stem (ES) cell line J1 (Li et al., 1992) and selection of G418-resistant transformants were performed as described previously (You-Ten et al., 1997). G418-resistant colonies were analyzed for homologous recombination by Southern blot analysis.

Mutant mice. Generation of chimeric and mutant mice was performed as described previously (You-Ten et al., 1997). Genotyping was performed by Southern blot analysis with probes derived from a $1.8 \mathrm{~kb}$ XbaI fragment located upstream of the targeting vector, a fragment derived from the 3' untranslated region of Eif4ebp2, or by duplex PCR with Oligo 1 (5' -GGTGGGACTGTCGGTCTTCTG), Oligo 2 (5' -CAGCACCTGGTCATAGCCGTG), and Oligo 3 (5'-GCATCGAGCGAGCACGTACTC). Heterozygous Eif4ebp2-targeted mice were initially derived on a mixed 129/SvJ and BALB/c genetic background. Congenic C57BL/6 Eif4ebp2 mutant mice were developed using marker-assisted breeding (Markel et al., 1997), with the assistance of the JAX Genome Services group from The Jackson Laboratory (Bar Harbor, ME).

Immunoblotting. Soluble protein extracts were prepared by homogenizing the tissue samples in ice-cold buffer C [50 mm Tris- $\mathrm{HCl}, \mathrm{pH} 7.5$, $150 \mathrm{~mm} \mathrm{KCl}, 1 \mathrm{~mm}$ DTT, $1 \mathrm{~mm}$ EDTA, $1 \times$ Complete protease inhibitor mixture (Roche, Indianapolis, IN), $1 \times$ Phosphatase Inhibitor Cocktail I (Sigma, St. Louis, MO), and $1 \times$ Phosphatase Inhibitor Cocktail II (Sigma)]. Proteins were resolved on SDS-polyacrylamide gels, and immunoblotting was performed as described previously (Poulin et al., 2003). A rabbit polyclonal antiserum raised against human GST-HMK$4 \mathrm{E}-\mathrm{BP} 2$ fusion protein (1:2500) was used to detect 4E-BP1 and 4E-BP2 (Gingras and Sonenberg, 1997). This antiserum strongly detects both $4 \mathrm{E}-\mathrm{BP} 1$ and 4E-BP2 from mouse, and it cross-reacts very weakly with 4E-BP3 (Tsukiyama-Kohara et al., 2001). The polyclonal anti-4E-BP3 antiserum (1:1000) was raised in a rabbit against mouse GST-4E-BP3 (Tsukiyama-Kohara et al., 2001), is specific to mouse 4E-BP3, and only weakly cross-reacts with 4E-BP1 and 4E-BP2 (Tsukiyama-Kohara et al., 2001). Total eIF4E, phospho-eIF4E, and phospho-Mnk1 antibodies (Cell Signaling, Beverly, MA) were diluted 1:1000 in 0.02\% I-Block (Tropix, Foster City, CA), and total Mnk1 (Santa Cruz Biotechnology, Santa Cruz, CA) was diluted 1:500 in 0.02\% I-Block. Anti-rabbit and anti-goat antibodies (Cell Signaling) were diluted 1:2500 in 0.02\% I-Block. All blots were developed using enhanced chemiluminescence. The bands of each Western blot were quantified from film exposures (Kodak BioMax; Eastman Kodak, Rochester, NY) in the linear range for each antibody and normalized to Ponceau $S$ total protein staining via densitometry using a desktop scanner and NIH Image software. Data represent the mean + SEM. Student's $t$ test was used for Western blot analysis with $p<0.05$ as significance criteria.

Electrophysiology. Transverse hippocampal slices $(400 \mu \mathrm{m})$ were prepared from age-matched males (10-16 weeks of age) using conventional techniques. Slices were maintained at $30^{\circ} \mathrm{C}$ in an interface chamber perfused with oxygenated artificial CSF (ACSF) containing the following (in mu): $125 \mathrm{NaCl}, 2.5 \mathrm{KCl}, 1.25 \mathrm{NaH}_{2} \mathrm{PO}_{4}, 25 \mathrm{NaHCO}_{3}, 25$ D-glucose, 2 $\mathrm{CaCl}_{2}$, and $1 \mathrm{MgCl}_{2}(2 \mathrm{ml} / \mathrm{min})$. When indicated, ACSF was supplemented with aminophosphonovaleric acid (APV; $50 \mu \mathrm{M}$; Tocris, Ellisville, MO), anisomycin (40 $\mu \mathrm{M}$; Calbiochem, San Diego, CA), cycloheximide (60 $\mu \mathrm{M}$; Calbiochem), actinomycin-D (40 $\mu \mathrm{M}$; Calbiochem), or U0126 (20 $\mu \mathrm{M}$; Cell Signaling). Extracellular field EPSPs (fEPSPs) were evoked by stimulation of the Schaeffer collateral pathway afferents and recorded in the CA1 stratum radiatum. Stable baseline synaptic transmission was established for 20 min with a stimulus intensity of $40-50 \%$ of the maximum fEPSP before LTP-inducing, high-frequency stimulation (HFS). Stimulus intensity of the HFS was matched to the intensity used in the baseline recordings. LTP was induced by either one train or four trains ( 5 min intertrain interval) of $100 \mathrm{~Hz}$ HFS for $1 \mathrm{~s}$ and one train or four trains ( 5 min intertrain interval) of theta burst stimulation (TBS; nine bursts of four pulses at $100 \mathrm{~Hz} ; 200 \mathrm{~ms}$ interburst interval), and measurements are shown as the average slope of the fEPSP from six individual traces collected over $2 \mathrm{~min}$ and standardized to baseline recordings. Post-tetanic potentiation (PTP) was induced by a single $100 \mathrm{~Hz}$ HFS train for $1 \mathrm{~s}$ after at least $20 \mathrm{~min}$ of stable baseline recordings in the presence of APV. Immediately after the HFS, fEPSPs were recorded every $3 \mathrm{~s}$ for $3 \mathrm{~min}$ and are presented as the average of four individual traces. 4E-BP2 knock-out and wild-type hippocampal slices were prepared simultaneously and placed in a chamber outfitted with dual-recording equipment, thereby minimizing day-to-day variability in slice preparations and recordings. Wild-type control LTP and 4E-BP2 knock-out control LTP data are recapitulated in Figure $4 A-D$. Two-way ANOVA and post-tests were used for electrophysiological data analysis with $p<$ 0.05 as significance criteria.

Biochemical analysis. Hippocampal area CA1 regions were dissected, and homogenates were prepared in ice-cold homogenization buffer containing protease inhibitors and phosphatase inhibitors 10 min after HFS. Coimmunoprecipitation experiments were performed in PBS containing phosphatase and protease inhibitors. Thirty micrograms of CA1 homogenate were precleared $1 \mathrm{~h}$ with a $50 \%$ protein A bead slurry and sequentially incubated with anti-eIF4G1 antibody $(10 \mu \mathrm{g})$ and $50 \%$ protein A slurry overnight at $4^{\circ} \mathrm{C}$. Western blot analysis was performed with phospho-specific antibodies against phospho-4E-BP (Thr36/47; 1:500), dual-phospho-Mnk1 (Thr200/220), and phospho-eIF4E (Ser209) (Cell Signaling) as described above.

Behavioral studies. For all behavioral tasks, 4E-BP2 knock-out and wild-type littermates (males, 3-4 months old) were used, and the experimenter was blind to mice genotypes. The training for the hidden platform version of the Morris water maze consisted of four trials $(60 \mathrm{~s}$ maximum; intertrial interval, $60 \mathrm{~min}$ ) each day for 7 consecutive days. The probe trial was administered $1 \mathrm{~h}$ after the completion of training on day 7. The visible platform task consisted of four trials (intertrial interval, $20 \mathrm{~min}$ ) each day for 2 consecutive days with the escape platform marked by a visible cue and moved randomly between four locations. The animals' trajectories were recorded with a video tracking system (HVS Image Analyzing VP-200). Data represent the mean + SEM. ANOVA and $\chi^{2}$ tests were used for statistical analysis with $p<0.05$ as significance criteria. The training sessions for contextual and cued fear conditioning consisted of a 3 min exploration period, followed by two conditioned stimulus (CS)-unconditioned stimulus (US) pairings separated by $1 \mathrm{~min}$ (footshock intensity: $0.5 \mathrm{~mA}, 2 \mathrm{~s}$ duration; tone: $85 \mathrm{~dB}$ white noise, $30 \mathrm{~s}$ duration). Context tests were performed in the training chamber after 1 and $24 \mathrm{~h}$. Cue tests were performed in a distinct chamber 2 or $24 \mathrm{~h}$ after training; baseline freezing was monitored ( $3 \mathrm{~min}$ ) before presentation of the tone ( $85 \mathrm{~dB}$ white noise, 3 min duration). Data represent the mean + SEM. Student's $t$ test was used for statistical analysis with $p<0.05$ as significance criteria.

\section{Results}

\section{Generation and characterization of 4E-BP2 knock-out mice}

An Eif4ebp2 targeting vector was designed to replace exon 2 with a neomycin-resistant cassette (Fig. $1 A$ ). The disrupted exon 2 encodes amino acids 49-110 of 4E-BP2, which encompass the binding site for eIF4E (Tsukiyama-Kohara et al., 1996). Correct targeting of the ES cell clones was verified with probes located 5' and 3 ' from the targeting vector (Fig. 1B). Eif4ebp2 disrupted ES cells were injected into BALB/c blastocysts, and germ-line transmission was achieved. Heterozygous mice were crossed to produce homozygous 4E-BP2 knock-out offspring (Fig. 1C). The number of 4E-BP2 knock-out offspring was consistent with Mendelian inheritance. The litters were of normal size, and the 


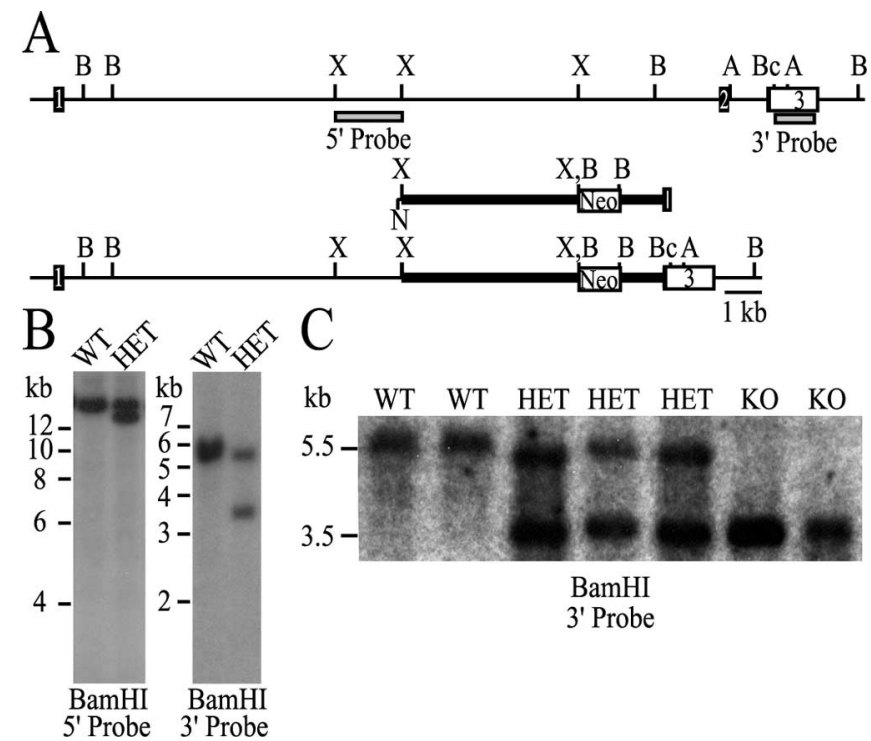

Figure 1. Targeted disruption of Eif4ebp2. A, Schematic representation of the mouse Eif4ebp2 gene (top), targeting vector (middle), and targeted gene (bottom). The coding region of exons 1 and 2 is displayed as a dark box, and the $3^{\prime}$ untranslated region is displayed as an open box. A neomycin (Neo) transferase expression cassette was substituted for the Eif4ebp2 Xbal-BCll fragment. A, B, BC, N, and X indicate the AfIIII, BamHI, BCll, Notl, and Xbal restriction enzyme sites, respectively. Not all $A$ fllll and $B C l l$ sites are shown. $B$, Southern blot analysis of wild-type and Eif4ebp2-targeted ES cell clones using the $5^{\prime}$ and $3^{\prime}$ probes depicted as gray boxes in $A$. C, Southern blot analysis of wild-type, Eif4ebp2-targeted, and homozygous knockout mice with the 3 ' probe. WT, Wild type; HET, Eif4ebp2 targeted; KO, knock-out.

mice developed normally. The knock-out mice were fertile and reproduced as well as the wild-type mice. No difference in life span was observed, and 4E-BP2 knock-out mice displayed no evidence of nonspecific illness or tumor development. A complete metabolic characterization revealed no significant alterations in general physiological function (data not shown). The Eif4ebp2 mutation was transferred to a C57BL/6 inbred background using marker-assisted breeding.

To verify that the 4E-BP2 knock-out mice did not express $4 \mathrm{E}-\mathrm{BP} 2$ protein in the brain, we conducted a Western blot analysis of hippocampal, cortical, and cerebellar extracts. We confirmed the absence of 4E-BP2 protein in the brain of the 4E-BP2 knock-out mice and found that the lack of 4E-BP2 was not accompanied by a compensatory increase in the protein levels of either 4E-BP1 or 4E-BP3 (Fig. $2 A$ ). Importantly, although 4E$\mathrm{BP} 2$ is expressed in many tissues, the ratio of $4 \mathrm{E}-\mathrm{BP} 2$ to $4 \mathrm{E}-\mathrm{BP} 1$ and $4 \mathrm{E}-\mathrm{BP} 3$ is very high in the brain. In fact, we detected a paucity of 4E-BP1 immunoreactivity and no 4E-BP3 immunoreactivity in the mouse brain (Fig. 2A). These findings contrast sharply with other organs such as liver, testis, colon, and spleen, in which the ratio of $4 \mathrm{E}-\mathrm{BP} 2$ to $4 \mathrm{E}-\mathrm{BP} 1$ and $4 \mathrm{E}-\mathrm{BP} 3$ is much lower (Tsukiyama-Kohara et al., 2001). These data are consistent with a tissue-restricted phenotype in the 4E-BP2 knock-out mice, as described below.

We proceeded to determine whether either eIF4E or its kinase Mnk1 was altered in the hippocampus of the 4E-BP2 knock-out mice using Western blot analysis. We did not detect alterations in either total levels of eIF4E or total levels of phosphorylated eIF4E in hippocampal tissue from the 4E-BP2 knock-out mice compared with wild-type littermate controls (Fig. 2B). Likewise, we detected no alterations in either total or phosphorylated Mnk1 in the $4 \mathrm{E}-\mathrm{BP} 2$ knock-out mice (Fig. $2 B$ ). We also examined the cytoarchitecture of various brain regions with cresyl violet stain-
A

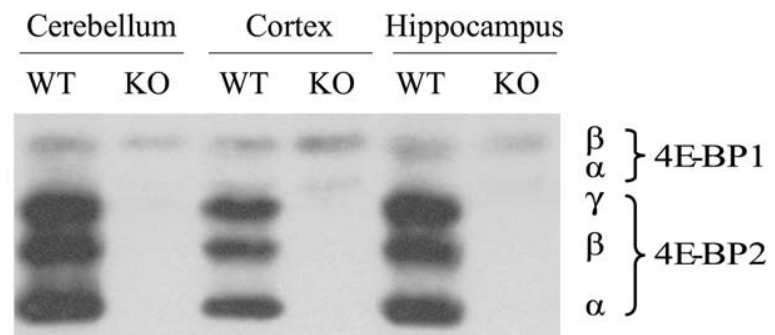

4E-BP3

actin

B

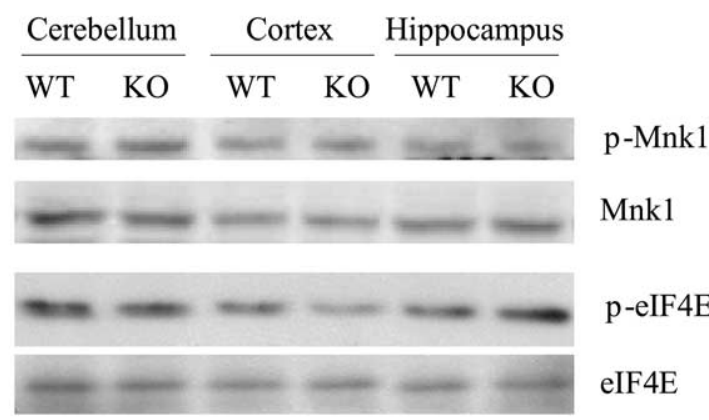

C

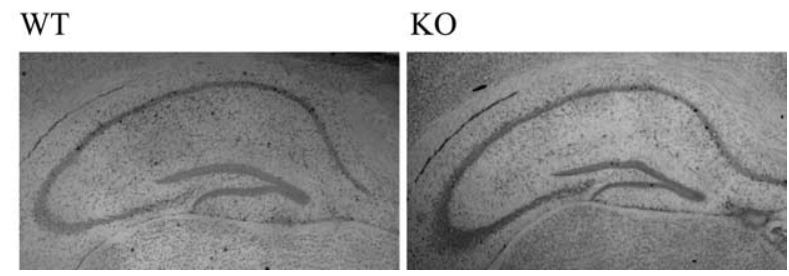

Figure 2. General characterization of $4 \mathrm{E}-\mathrm{BP} 2$ knock-out mice. $\boldsymbol{A}$, Representative Western blot analysis of $4 \mathrm{E}-\mathrm{BP} 1,4 \mathrm{E}-\mathrm{BP} 2,4 \mathrm{E}-\mathrm{BP} 3$, and actin in different brain regions obtained from wild-type or knock-out mice. $\alpha, \beta$, and $\gamma$ identify 4E-BP1 and 4E-BP2 phosphorylation isoforms that exhibit different electrophoretic mobilities in SDS-PAGE. $B$, Representative Western blot analysis of phosphorylated and total protein levels of elF4E and Mnk1 in different brain regions show no difference. $\boldsymbol{C}$, Representative cresyl violet staining of hippocampal cell bodies in slices obtained from wild-type (left) and knock-out (right) mice show no difference. WT, Wild type; KO, knock-out.

ing and observed no obvious abnormalities in the 4E-BP2 knockout mice compared with wild-type mice, including the hippocampus (Fig. 2C), cerebellum, and cortex (data not shown). Thus, at the metabolic, biochemical, and neuroanatomical levels, the 4E-BP2 knock-out mice appeared to be identical to their wild-type littermates.

\section{Loss of 4E-BP2 expression does not affect basal synaptic activity}

We investigated whether the lack of 4E-BP2 expression had effects on hippocampal plasticity in the Schaffer collateral-CA1 synaptic pathway by recording fEPSPs. As an initial step in our analysis, we examined basal synaptic function. If 4E-BP2 activity 
functions as an activity-dependent switch for the commencement of translation and generation of LTP, then loss of 4E-BP2 expression might increase basal synaptic transmission and occlude further attempts to elicit LTP. We did not find this to be the case. Basal synaptic transmission was normal in 4E-BP2 knock-out mice, as evidenced by similar synaptic input-output relationships in wild-type and 4E-BP2 knock-out mice (Fig. 3A). Similarly, we found no significant differences between the mean ratios of fEPSP slopes to presynaptic fiber volley amplitudes in wild-type and 4E-BP2 knock-out mice: mean ratios were $2.16 \pm 0.13 \mathrm{~ms}^{-1}$ for wild-type slices and $2.37 \pm 0.24 \mathrm{~ms}^{-1}$ for $4 \mathrm{E}-\mathrm{BP} 2$ knockout slices $(n=17$ slices; 10 mice per genotype; $p>0.4)$. Thus, baseline synaptic transmission appears to be unaltered in the hippocampus of 4E-BP2 knock-out mice.

Because there is evidence for a protein synthesis-dependent, presynaptic contribution during invertebrate synaptic plasticity (Martin et al., 1997; Beaumont et al., 2001), we next investigated paired-pulse facilitation (PPF), a presynaptic enhancement of transmission that is observed in the second of two closely spaced stimuli (Katz and Miledi, 1968). PPF was normal in 4E-BP2 knock-out mice at multiple interpulse intervals (Fig. $3 B$ ). We also examined an additional form of short-term synaptic plasticity, PTP. PTP is a transient enhancement of AMPA receptormediated fEPSP slopes that is observed immediately after highfrequency synaptic stimulation, or tetanization. We found that a single $100 \mathrm{~Hz}$ train administered in the presence of the NMDA receptor antagonist APV elicited normal PTP in 4E-BP2 knockout slices relative to wild-type controls (Fig. 3C). Together, our tests of basal synaptic function and short-term forms of synaptic plasticity demonstrate that genetic elimination of the translation repressor $4 \mathrm{E}-\mathrm{BP} 2$ did not perturb the ability of CA1 neurons to respond to controlled presynaptic stimulation.

\section{E-BP2 knock-out mice convert early-phase LTP to late-phase LTP that is sensitive to inhibitors of translation, transcription, and mitogen-activated protein kinase kinase} Removal of 4E-BP2 eliminates sequestration of eIF4E and favors eIF4F complex formation and the initiation of mRNA translation (Gingras et al., 1999). Although the loss of 4E-BP2 expression appears not to affect basal synaptic transmission, it might enhance the ease with which macromolecular synthesis-dependent late-phase LTP (L-LTP) is elicited. To test this hypothesis, we first used a standard $100 \mathrm{~Hz}$ tetanus train of HFS with a $1 \mathrm{~s}$ duration that normally produces a nonsaturating, short-lasting earlyphase LTP (E-LTP). In wild-type mice, this single train of HFSinduced LTP began to approach baseline after $2 \mathrm{~h}$. In 4E-BP2 knock-out mice, the same stimulation evoked LTP with a similar initial magnitude, but with an enhanced and sustained maintenance phase (Fig. $4 A$ ). Strikingly, the absence of 4E-BP2 in the knock-out mice allows a stimulus that normally elicits only E-LTP in wild-type mice, to elicit a facilitated LTP that appears to be similar to L-LTP in duration.

The hallmark characteristic of L-LTP is the requirement for new RNA and protein synthesis. We were interested in determining the extent to which the facilitated LTP in 4E-BP2 knock-out mice depended on such macromolecular synthesis. One train of HFS delivered in the presence of anisomycin, a translation inhib-
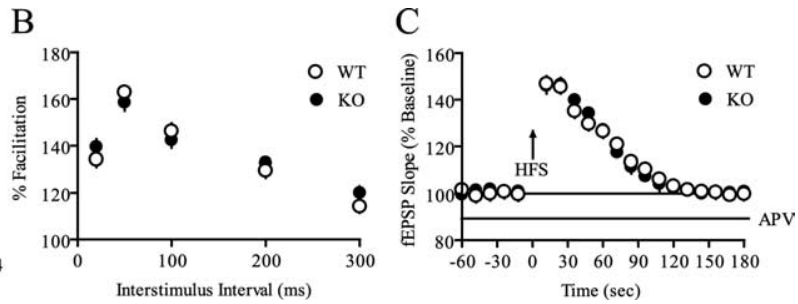

itor, produced a progressive inhibition of the facilitated LTP in 4E-BP2 knock-out slices (Fig. 4B). Similar results were observed with an alternative translation inhibitor, cycloheximide (Fig. $4 E$ ). In fact, the LTP evoked in the 4E-BP2 knock-out slices exposed to anisomycin strongly resembled the E-LTP evoked in the wildtype counterparts (Fig. 4 B). Actinomycin-D, an irreversible transcription inhibitor, also inhibited the facilitated LTP in 4E-BP2 knock-out slices when delivered with the same incubation pattern as anisomycin (Fig. 4C) or washed out 10 min before HFS (data not shown). In agreement with previous reports, neither anisomycin nor actinomycin-D affected wild-type E-LTP (Frey et al., 1988, 1996; Nguyen et al., 1994) (data not shown). Interestingly, the temporal sensitivity to the inhibitors differed significantly: anisomycin caused a progressive inhibition of LTP, whereas actinomycin-D produced a delayed pattern of LTP inhibition (Fig. $4 B, C, E$ ). These data are consistent with increasing evidence for two distinct phases of L-LTP: an early transcriptionindependent, translation-dependent phase and a later phase that is dependent on both transcription and translation (Nguyen et al., 1994; Frey et al., 1996; Frey and Morris, 1997, 1998; Kelleher et al., 2004).

We have shown previously that NMDA receptor activation results in increased phosphorylation of eIF4E in hippocampal area CA1 that was blocked by inhibition of mitogen-activated protein kinase kinase (MEK), the upstream kinase necessary for activation of extracellular signal-regulated kinase (ERK) (Banko et al., 2004). Furthermore, it has been shown that eIF4E phosphorylation is increased after L-LTP-inducing stimulation and that this increase is prevented in mice that express a dominantnegative MEK (Kelleher et al., 2004). To determine whether MEK-ERK signaling contributed to the facilitated E-LTP evoked in $4 \mathrm{E}-\mathrm{BP} 2$ knock-out mice, we induced LTP in the presence of the MEK inhibitor U0126. We found that U0126 attenuated the magnitude of the LTP evoked in the 4E-BP2 knock-out mice, although the knock-out mice did exhibit more potentiation than their wild-type counterparts after $3 \mathrm{~h}$ (Fig. 4D). These results suggest that the mechanism that subserves the enhanced LTP in 4E-BP2 knock-out mice has both ERK-dependent and -independent components.

Together, genetic elimination of 4E-BP2 enables weak stimulation to evoke the expression of a facilitated LTP in the Schaffer collateral pathway that resembles wild-type L-LTP in its duration, kinetic pattern of sensitivity to inhibition of RNA and protein synthesis, and dependence on ERK activation. 
A

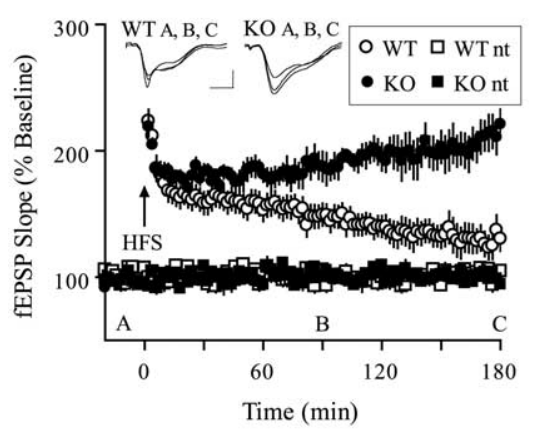

B

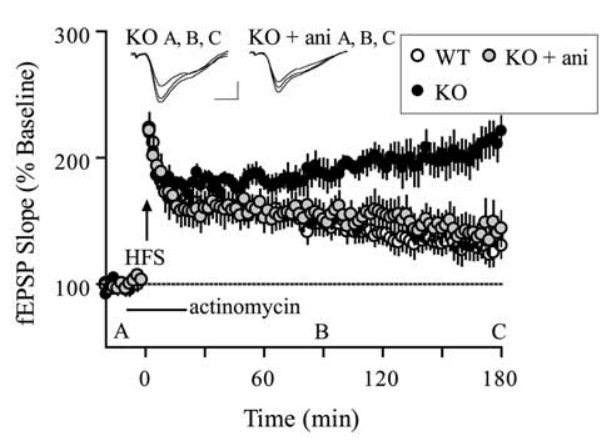

C

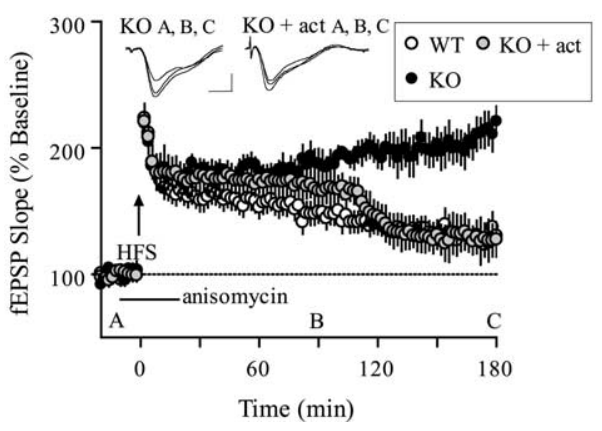

Figure 4. Facilitated L-LTP in 4E-BP2 knock-out mice. A, A single $100 \mathrm{~Hz}$ train (1 s) evoked E-LTP in wild-type slices that decayed to baseline after $3 \mathrm{~h}$ but evoked L-LTP in knock-out slices that endured for at least $3 \mathrm{~h}$ ( $n=10$ slices; 8 mice per genotype; $p<0.0001$; ANOVA). Representative fEPSP recordings from time points $A, B$, and ( are shown for each condition. Calibration: 1 $\mathrm{mV}, 10 \mathrm{~ms}$. $\boldsymbol{B}$, Facilitated LTP induced by one $100 \mathrm{~Hz}$ train in knock-out slices was reversed by anisomycin (ani; $40 \mu \mathrm{m}$ ) after $45 \mathrm{~min}$ to a level indiscernible from wild-type slices (wild-type, $n=10 ;$ knock-out, $n=10 ; \mathrm{KO}+$ ani, $n=8 ; p<0.0001 ;$ ANOVA). C, Facilitated LTP induced by one $100 \mathrm{~Hz}$ train in knock-out slices was reversed by actinomycin-D (actino; $40 \mu \mathrm{M}$ ) after 90 min to a level indiscernible from wild-type slices (wild-type, $n=10$; knock-out, $n=10 ; \mathrm{KO}+$ actino, $n=8 ; p<0.0001 ;$ ANOVA). D, Facilitated L-LTP-induced $100 \mathrm{~Hz}$ train in knock-out slices was attenuated by U0126 (20 $\mu \mathrm{m})$ (wild-type, $n=10 ; \mathrm{knock}$-out, $n=$ $10 ; \mathrm{KO}+\mathrm{U} 0126, n=8 ; p<0.0001 ;$ ANOVA). $\boldsymbol{E}$, Compilation bar graph depicting average fEPSP slopes for the time periods indicated. ${ }^{*} p<0.05$ ( $t$ test) compared with knock-out for the given time periods. WT, Wild-type; K0, knock-out.

\section{Multiple and spaced stimuli-induced LTP deficits in 4E-BP2 knock-out mice}

The finding that the loss of the translation repressor 4E-BP2 produces a shift in the threshold for the induction of L-LTP by HFS suggested the possibility that other stimulation protocols might also reveal changes in synaptic plasticity in the Schaffer collateral pathway. It was reported recently that a single train of TBS (nine bursts of four pulses at $100 \mathrm{~Hz} ; 200 \mathrm{~ms}$ interburst interval) produces long-lasting LTP that is protein synthesis dependent and can be inhibited by rapamycin (Alarcon et al., 2004). Because $4 \mathrm{E}-\mathrm{BP}$ activity is sensitive to rapamycin, we hypothesized that LTP evoked by this paradigm might also be altered in our knock- out mice. However, we found that LTP induced by a single train of TBS was similar in the wild-type and 4E-BP2 knock-out mice (Fig. 5A). This observation is consistent with the notion that single-train TBSinduced LTP is associated with an mRNA 3' end-regulated mechanism of translation initiation (Alarcon et al., 2004).

It is well known that multiple and spaced stimuli induce very robust and long-lasting LTP that is dependent on new protein synthesis. We therefore examined LTP induced by protocols that use stronger stimulation $(4 \times$ HFS or $4 \times$ TBS; 5 min intertrain interval). Multiple trains of HFS produced stereotypic L-LTP in wildtype slices. To our surprise, the potentiation evoked in the 4E-BP2 knock-out mice decayed steadily to baseline in $<2 \mathrm{~h}$ (Fig. $5 B$ ). Importantly, the 4E-BP2 knock-out mice not only were unable to maintain potentiation, they did not achieve the same degree of initial potentiation (Fig. 5B). Similarly, multiple rounds of TBS were inefficient in producing a robust L-LTP in the slices from 4E-BP2 knock-out mice compared with wild-type slices (Fig. 5C). The electrophysiology experiments described here point toward a 4E-BP2dependent mechanism that, if engaged during E-LTP, is sufficient to convert the E-LTP to L-LTP and the proper regulation of which is paramount for L-LTP induced by multiple, spaced stimuli.

\section{eIF4F complex formation during LTP is} regulated by $4 \mathrm{E}-\mathrm{BP} 2$

The ability of one train of HFS to evoke translation-dependent LTP in the 4E-BP2 knock-out mice suggests the possibility that under normal circumstances, translation factors necessary for cap-dependent translation are activated during HFSinduced E-LTP. This notion is consistent with previous reports describing a similar translation-dependent conversion of short-lasting plasticity to long-lasting plasticity in several different species that have undergone genetic manipulation (Barco et al., 2002). In support of this hypothesis, we found that one train of LTPinducing HFS produced an increase in 4E-BP2 phosphorylation in area CA1 of wild-type mice that rivaled in magnitude those levels induced by four trains of HFS (Fig. 6A). We also found that phosphorylation of Mnk1 and eIF4E was increased after both one and four trains of HFS (Fig. 6B, C). Notably, the magnitude of the phospho-Mnk1 and phospho-eIF4E changes increased proportionately with the strength of the stimulation delivered. It is possible that there was a localized additional increase in 4E-BP2 phosphorylation with additional trains of HFS that was undetected by our sample preparation. Phosphorylation of eIF4E reduces its affinity for the 5' cap of the mRNA (Niedzwiecka et al., 2002; Scheper et al., 2002; Zuberek et al., 2003, 2004) and is thereby 
thought to provide a means in which to recycle eIF4E for use on different mRNAs. A more direct method of assessing the cellular competency for translation initiation is to investigate formation of the eIF4F complex. In wild-type mice, both one train and four trains of HFS produced an increase in the quantity of eIF4E that coimmunprecipitated with an antibody against eIF4G that also was positively correlated with the degree of stimulation delivered (Fig. 6D).

The level of the basal eIF4F complex was elevated in the 4E-BP2 knock-out mice to a degree that resembles eIF4F levels after one train of HFS in the wild-type slices (Fig. 6D). Furthermore, we found that HFS induced an even greater increase in the quantity of the eIF4F complex in the 4E-BP2 knock-out slices than the wild-type slices (Fig. 6D) and that the increase can be correlated to the amount of stimulation delivered (Fig. 6D). These results suggest that there are more eIF4F complexes available to initiate translation in the 4E-BP2 knock-out mice.

Overall, these data provide direct evidence for the activation of cap-dependent translation factors during both E-LTP and L-LTP in wild-type mice. Furthermore, the results of these analyses reveal both enhanced basal and enhanced HFS-induced eIF4F complex formation in 4E-BP2 knock-out mice, a biochemical mechanism that may explain why L-LTP can be elicited by one train of HFS in slices from 4E-BP2 knock-out mice. Excessive activation of the eIF4F complex and translation initiation as observed in the 4E-BP2 knock-out mice after four trains of HFS may result in downstream events that prohibit L-LTP such as nonspecific translation of protein species that are detrimental to the maintenance of L-LTP.

\section{E-BP2 knock-out mice show impaired learning and long-term memory}

To explore potential behavioral effects of $4 \mathrm{E}-\mathrm{BP} 2$ on spatial learning, we trained mice on the hidden platform version of the Morris water maze, a hippocampus-dependent spatial learning task that measures the ability of an animal to learn and remember the relationship between multiple distal cues and the location of the platform (Morris, 1984). During acquisition, wild-type and $4 \mathrm{E}-\mathrm{BP} 2$ knock-out mice showed a decrease in escape latency (Fig. $7 A$ ) and path length (data not shown) across days, indicating learning of the platform position. However, despite the day-today improvement, the 4E-BP2 knock-out mice displayed significantly higher escape latencies (Fig. 7A) and longer path lengths than control mice overall (data not shown). These results indicate that the 4E-BP2 knock-out mice exhibit a spatial learning impairment.

To assess spatial memory, we tested mice in a probe trial during which the platform was removed from the pool and the mice were allowed to search for $60 \mathrm{~s}$ ( $1 \mathrm{~h}$ after the completion of the last training trial). The time spent in each quadrant measures the spatial bias of an animal's search pattern (Schenk and Morris, 1985). Unlike their wild-type counterparts, the 4E-BP2 knockout mice did not display a preference for the pool quadrant in which the platform was located during training (Fig. 7B) and crossed the exact site where the platform was located during training fewer times (Fig. 7C). These findings demonstrate com-
B
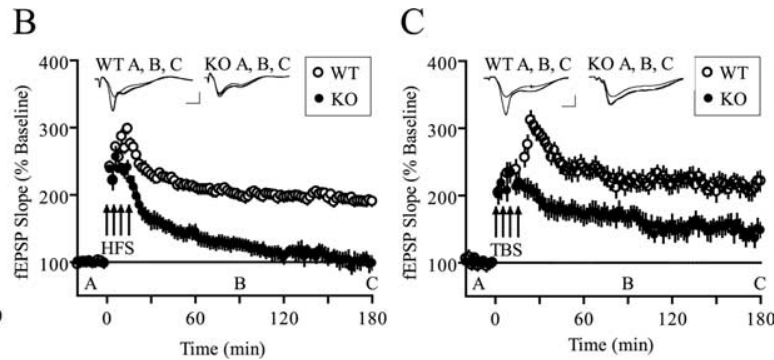

Figure 5. L-LTP-inducing stimuli evoke altered LTP in 4E-BP2 knock-out mice. $\boldsymbol{A}$, TBS-induced LTP is similiar in knock-out and witd 0.0001; ANOVA). C, Four trains of TBS separated by 5 min each evoked a robust L-LTP in wild-type slices but not in knock-out slices

promised spatial learning and memory in the 4E-BP2 knock-out mice.

To examine the possibility that the spatial learning deficit in the $4 \mathrm{E}-\mathrm{BP} 2$ knock-out mice might be attributable to poor vision, motivation, or swimming ability, we tested naive mice on a visible platform task in which mice learned to associate a distinct visible cue (a red flag) with an escape platform. The position of the platform and swim-start position varied from trial to trial. Mice lacking 4E-BP2 were not different from control mice in latencies to find the platform or swim speed in this task (Fig. $7 \mathrm{D}$ and data not shown). Together, the water maze experiments reveal that the lack of 4E-BP2 specifically impairs spatial learning and memory but not visual acuity, swimming ability, or motivation to escape from the water.

To determine how the lack of 4E-BP2 affects associative learning and memory formation, we tested mice using a conditioned fear paradigm, in which animals learn to fear a new environment or an emotionally neutral CS (tone) because of its temporal association with an aversive US (footshock). When exposed to the same context (contextual conditioning) or tone (cued conditioning) at a later time, conditioned animals demonstrate the stereotypical fear response, freezing (Fanselow, 1984; Phillips and LeDoux, 1992).

For contextual and cued conditioning, mice were trained with two CS-US pairings during initial context exploration. The 4EBP2 knock-out mice and wild-type mice responded comparably to the training paradigm (Fig. $8 A$ ) and showed similar acquisition of short-term memory for the context and the CS (Fig. $8 B$ ). This indicates that mice lacking 4E-BP2 have normal associative learning and unaltered short-term memory. There also was no difference between genotypes tested with the CS 24 h later (Fig. $8 \mathrm{~B}$ ). In contrast, $4 \mathrm{E}-\mathrm{BP} 2$ knock-out mice showed a significant reduction in long-term memory for the context relative to their wild-type counterparts when tested $24 \mathrm{~h}$ after training (Fig. $8 \mathrm{~B}$ ). These results suggest a critical role for $4 \mathrm{E}-\mathrm{BP} 2$ in the consolidation of contextual conditioned fear-associative memories.

\section{Discussion}

Our studies characterizing 4E-BP2 knock-out mice were designed to define mechanisms responsible for the regulation of translation initiation during LTP and memory formation. Determination of the regulatory mechanisms that govern translation initiation that are engaged during activity-dependent synaptic plasticity should be useful in identifying the mRNAs that are translated in an activity-dependent manner. We found that genetic elimination of the cap-dependent translation repressor 4E- 
A
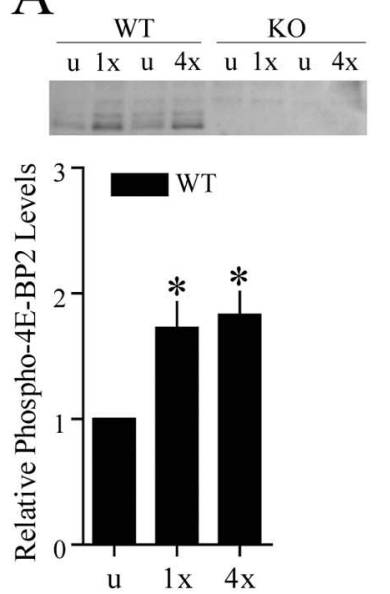

B
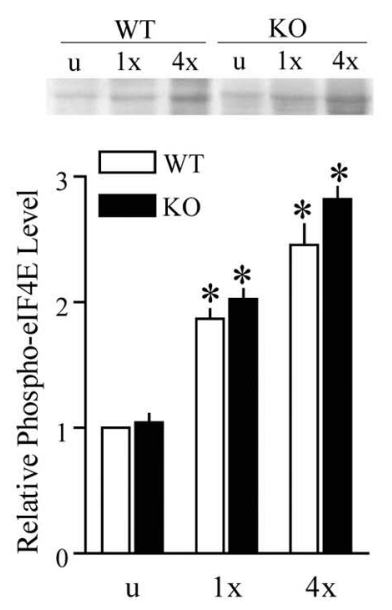

$\mathrm{C}$
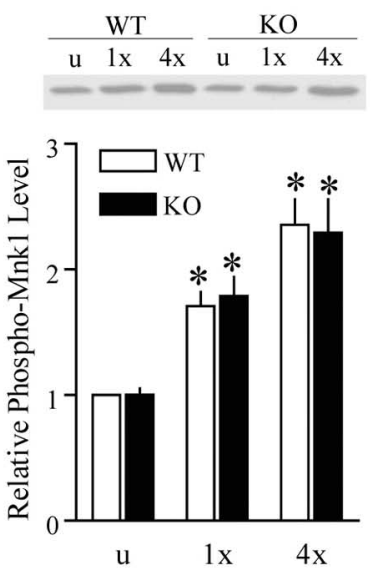

$\mathrm{D}$

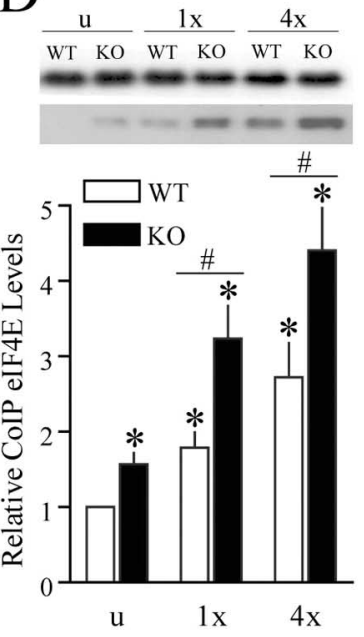

Figure 6. Regulation of translation initiation factors during LTP. A, HFS-induced 4E-BP2 phosphoryation (Thr36/47) in area CA1 homogenates obtained from wild-type and knock-out slices ( $n=4$ slices per genotype). ${ }^{*} p<0.05$ ( $t$ test) compared with wild type unstimulated. Total protein loading was normalized by Ponceau $S$ membrane staining. $\boldsymbol{B}$, HFS-induced elF4E phosphorylation (Ser 209) in area CA1 homogenates obtained from wild-type and knock-out slices ( $n=6$ slices per genotype). ${ }^{*} p<0.05$ ( $t$ test) compared with wild type unstimulated. Total protein loading was normalized by Ponceau S membrane staining. C, HFS-induced Mnk1 phosphorylation (Thr100/220) in area CA1 homogenates obtained from wild-type and knockout slices $\left(n=6\right.$ slices per genotype). ${ }^{*} p<0.05$ ( $t$ test) compared with wild type unstimulated. Total protein loading was normalized by Ponceau $S$ membrane staining. $\boldsymbol{D}$, HFS-induced elF4EelF4G coimmunoprecipitation in area CA1 homogenates obtained from wild-type and knockout slices ( $n=6$ slices per genotype). ${ }^{*} p<0.05$ ( $t$ test) compared with wild type unstimulated; ${ }^{\#} p<0.05$ ( $t$ test) between samples indicated by the bar. WT, Wild-type; KO, knock-out.

BP2 lowered the threshold for induction of L-LTP in the hippocampus and was accompanied by enhanced eIF4F complex formation. In addition, we found that $4 \mathrm{E}-\mathrm{BP} 2$ is required for spatial learning and memory and context-dependent associative fear memory. Together, these findings reveal explicit genetic evidence delineating a role for the regulation of cap-dependent translation initiation in synaptic plasticity and memory formation and address a current void in our understanding of how activity-dependent protein synthesis is regulated during these neuronal processes.

\section{Translation initiation and E-LTP}

The regulatory mechanisms of activity-dependent RNA and protein synthesis are often studied by varying the parameters of

A

$\mathrm{C}$
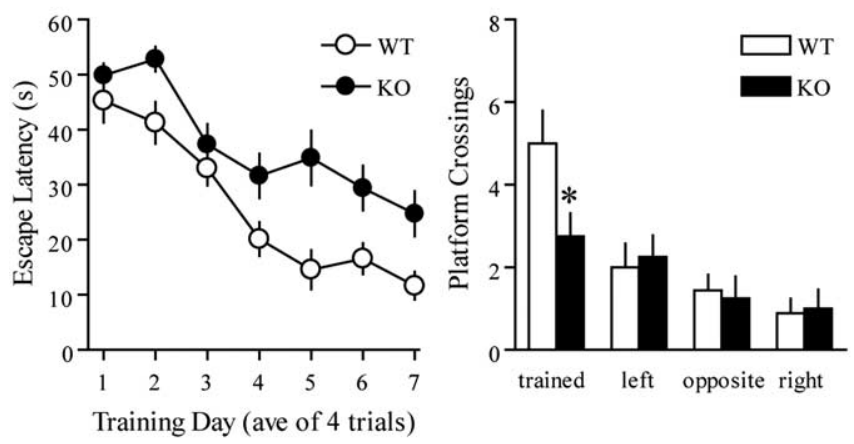

B

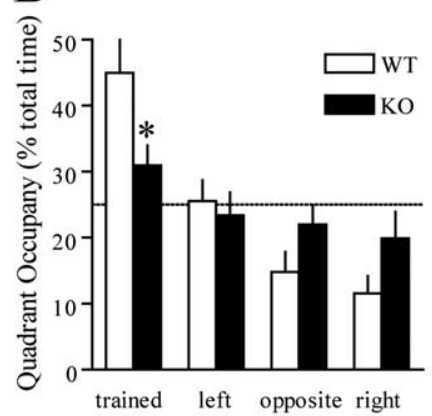

$\mathrm{D}$

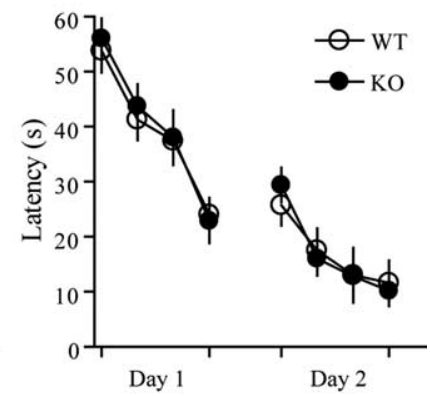

Figure 7. Impaired spatial learning and memory in 4E-BP2 knock-out mice. A, Escape latencies in the hidden platform Morris water maze plotted as a function of training day ( $n=12$ mice per genotype; $p<0.0001 ; A N O V A)$. $\boldsymbol{B}$, The mean proportion of time spent in each of the quadrants during the probe test represented for both groups. $C$, The mean number of platform location crossings during the probe trial shown for the training quadrant and the corresponding locations in other quadrants. $D$, Cued-platform control task ( $n=8$ mice per genotype; $p>$ 0.05; ANOVA). WT, Wild-type; KO, knock-out.

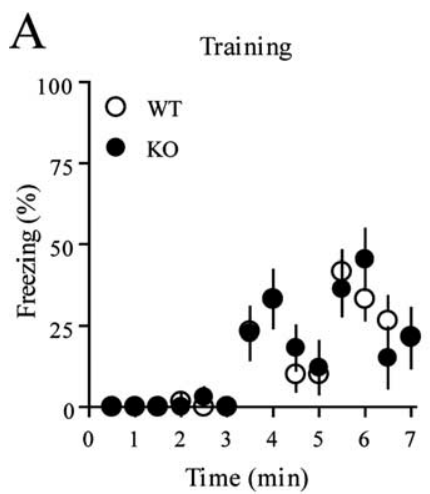

B

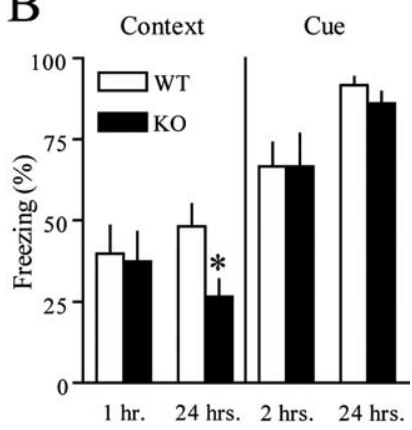

Figure 8. Impaired conditioned fear memory in 4E-BP2 knock-out mice. $A$, Wild-type ( $n=$ 22) and knock-out $(n=20)$ mice responded comparably during training with a paradigm of a tone paired with a footshock between $3-4$ and $5-6 \mathrm{~min}$. $\boldsymbol{B}$, Mean freezing behavior is shown from the contextual fear response test performed $1 \mathrm{~h}$ (wild-type, $n=10$; knock-out, $n=8$ ) or $24 \mathrm{~h}$ (wild-type, $n=12$; knock-out, $n=10$ ) after training ( ${ }^{*} p<0.05$; Student's $t$ test). Mean freezing behavior is shown from the cued fear response test performed $2 \mathrm{~h}$ (wild-type, $n=10$; knock-out, $n=8$ ) or $24 \mathrm{~h}$ (wild-type, $n=12$; knock-out, $n=10$ ) after training. WT, Wild-type; K0, knock-out.

L-LTP induction, because inhibition of either transcription or translation blocks L-LTP and does not appear to reduce the magnitude or duration of E-LTP (Stanton and Sarvey, 1984; Frey et al., 1988; Huang and Kandel, 1994; Abel et al., 1997). Such investigations presume that activity-dependent mRNA translation is negligible during short-lasting LTP. However, the results of our 
investigation are consistent with the idea that translation initiation can be triggered with E-LTP-inducing stimulation. We observed that one train of HFS increased phosphorylation of 4E-BP2 minutes after delivery of the stimulation, which was accompanied by an increase in eIF4F complex formation, activation of Mnk1, and a subsequent enhancement in eIF4E phosphorylation (Fig. 6). Thus, although not necessary for the expression of E-LTP, the signaling mechanisms that regulate cap-dependent translation initiation are engaged by stimulation that induces E-LTP.

Advantages of activating components of the initiation pathway during E-LTP may include marking a stimulated synapse for the future capture of L-LTP. Speculation regarding activitydependent synaptic marking and the nature of candidate synaptic markers has been offered in the "synaptic tagging" hypothesis. Initially, synaptic tagging was regarded as a protein synthesisindependent event, because anisomycin was ineffective at blocking the phenomenon (Frey and Morris, 1997). However, there are numerous subsequent examples of protein synthesisdependent synaptic tagging in both invertebrates and mammals (Casadio et al., 1999; Barco et al., 2002; Martin and Kosik, 2002; Si et al., 2003). Moreover, the biochemical changes we observed in eIF4E, eIF4F, and Mnk1 during E-LTP occur upstream of the actions of anisomycin. Therefore, it is conceivable that the formation of the eIF4F complex itself or the protein products of the ensuing cap-dependent translation may serve as components of the synaptic tag.

\section{Induction of L-LTP is facilitated in 4E-BP2 knock-out mice}

We demonstrated that lack of the translational repressor 4E-BP2 facilitates the establishment of long-lasting LTP in the Schaffer collateral pathway by allowing a single train of HFS that normally produces E-LTP instead to produce L-LTP at these synapses. This facilitated L-LTP shared hallmark characteristics of the classic, multiple-train, HFS-induced L-LTP in that it was sensitive to inhibitors of translation, transcription, and MEK (Fig. 4). Interestingly, the finding that the facilitated L-LTP in the 4E-BP2 knock-out mice requires transcription suggests that in addition to translation, transcription may also be engaged with one train of HFS, provided that translation initiation is enhanced.

Previous studies have used eIF4E phosphorylation as an index of translation initiation. However, the correlation between increased phosphorylation levels of eIF4E and increased rates of protein synthesis remain controversial. A more accurate readout of the cellular competency for translation initiation is the assembly of the eIF4F initiation complex. Here, we demonstrated an activity-induced eIF4F complex assembly in wild-type mice that paralleled the strength of stimulation delivered (Fig. 6). These findings suggest a mechanism that is consistent with a previous report of increased incorporation of radiolabled methionine into proteins during L-LTP (Kelleher et al., 2004). Examination of activity-induced eIF4F complex formation in the 4E-BP2 knockout mice revealed that there is more eIF4F complex available to initiate translation. These findings support the hypothesis that the apparent shift in the threshold for the induction of L-LTP in the 4E-BP2 knock-out mice is a consequence of enhanced translation initiation. Thus, increasing the cellular capacity for translation initiation, via elevating eIF4F complex levels, for example, lowers the stimulation threshold for the consolidation of L-LTP. However, increasing the cellular capacity for L-LTP is not without limits. Indeed, it was reported previously that the loss of $\mathrm{G}(\mathrm{i} \alpha 1)$ resulted in enhanced HFS-induced hippocampal LTP in area CA1 and long-term memory deficits, raising the possibility that amplifying the responsiveness of CA1 postsynaptic neurons to stimuli that strengthen synaptic efficacy diminishes synapsespecific plasticity required for new memory formation (Pineda et al., 2004).

\section{Activity-dependent translation initiation: How much is too much?}

We found that several components of the translation initiation machinery are regulated after HFS in such a way as to facilitate activity-dependent protein synthesis. Not surprisingly, the magnitude of these changes increased proportionately with the strength of the stimulation delivered. For example, we observed that multiple, spaced trains of HFS were associated with greater increases in Mnk1 phosphorylation, eIF4E phosphorylation, and eIF4F complex levels compared with one train of HFS. Curiously, $4 \mathrm{E}-\mathrm{BP} 2$ phosphorylation did not follow the same pattern (Figure 6 ). We did not observe an additional increase in 4E-BP2 phosphorylation after multiple, spaced trains of HFS compared with one train of HFS, a mechanism that may have evolved to prevent excessive eIF4E liberation. Indeed, when multiple, spaced trains of HFS were delivered to 4E-BP2 knock-out mice, we observed similar increases in Mnk1 phosphorylation and eIF4E phosphorylation to wild type but an almost twofold greater increase in the eIF4F complex available to initiate translation (Fig. 6). The observation that HFS increased the levels of the eIF4F complex compared with basal conditions in the 4E-BP2 knock-out animals indicates that additional eIF4E-regulatory proteins are involved in activity-induced formation of the eIF4F complex. The absence of additional 4E-BP2 phosphorylation after additional trains of HFS would enable the unphosphorylated pool of 4E-BP2 to recover the newly liberated eIF4E from these additional regulatory proteins, thereby ensuring that the amount of eIF4F complex association and translation initiation achieved does not reach excess, the consequences of which could include compromised mRNA selectivity. Together with the observation that multiple, spaced trains of stimuli failed to generate L-LTP in the 4E-BP2 knock-out mice (Fig. 5), these findings suggest that L-LTP induction may be reliant on a mechanism of homeostatic control over the quantity eIF4F complex that is governed by 4E-BP2.

During translational quiescence in Xenopus oocytes, a protein termed maskin is associated with both CPEB located at the $3^{\prime}$ end of the mRNA and eIF4E (Stebbins-Boaz et al., 1999). Translation initiation is coincident with the phosphorylation of cytoplasmic polyadenylation element-binding protein (CPEB) by either Aurora or CaMKII (calcium/calmodulin-dependent protein kinase II) and the subsequent dissolution of the maskin-eIF4E interaction (Stebbins-Boaz et al., 1999; Cao and Richter, 2002; Atkins et al., 2004). A mammalian homolog of maskin has not yet been described; however, a requirement for CPEB in the stabilization of TBS-induced LTP was demonstrated recently (Alarcon et al., 2004). Given these observations, it is reasonable to hypothesize that, under normal circumstances, 4E-BP2 and CPEB-associated eIF4E regulatory proteins regulate the quantity of eIF4E available to initiate translation.

\section{A molecular model for the regulation of activity-dependent translation initiation}

L-LTP is often used as an experimental model for delineating the molecular substrates of long-term memory formation, and several of the mechanisms that underlie the induction and stabilization of L-LTP also have been shown to operate during learning and memory (Silva, 2003). Notably, the role of protein synthesis in these aforementioned processes has been demonstrated by the 

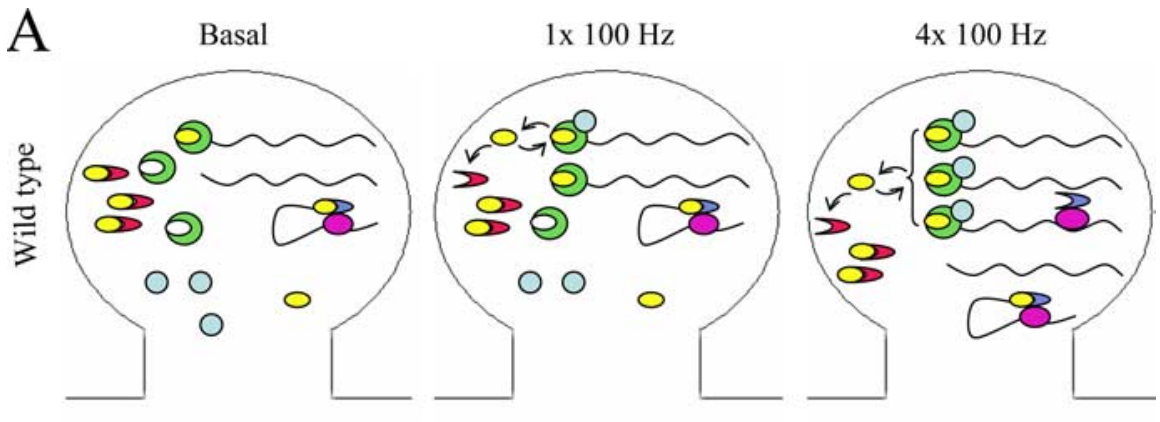

\section{B}

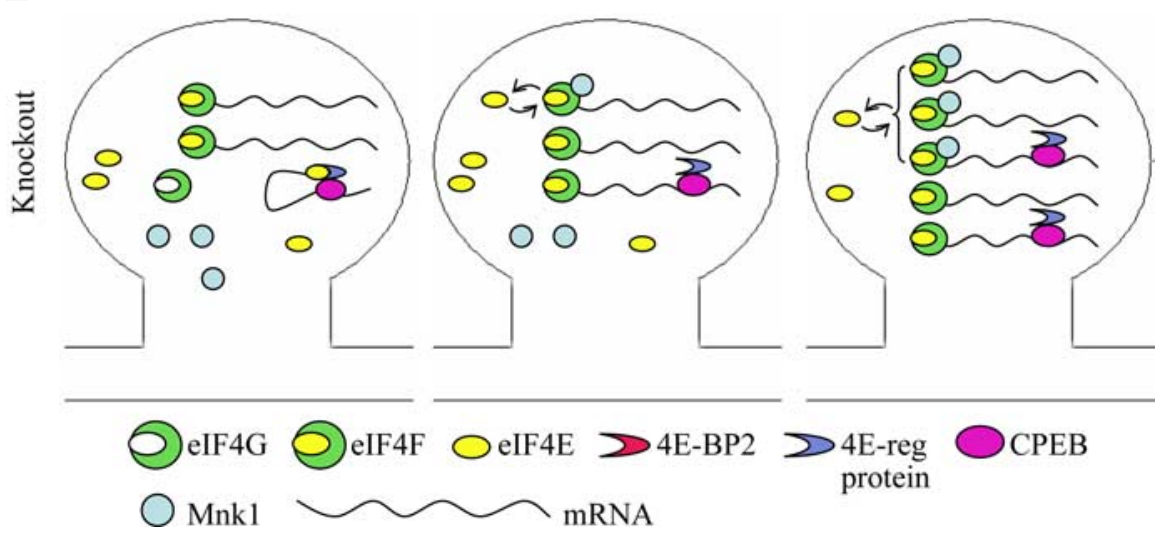

Figure 9. A molecular model for activity-induced translation initiation. $A, 0$ ne $100 \mathrm{~Hz}$ train stimulation elicits E-LTP in wildtype mice, a process that does not require protein synthesis but engages translation initiation factors. elF4E availability for elF4G binding and elF4F complex formation increases as a result of $4 \mathrm{E}-\mathrm{BP} 2$ phosphorylation. elF4G-bound elF4E is phosphorylated by Mnk1 and can be reused for initiation or recovered by 4E-BP2. Four $100 \mathrm{~Hz}$ trains elicit L-LTP in wild-type mice, a process that requires mRNA production and protein synthesis. L-LTP results in more robust activation of the translation initiation factors, including release of elF4E from additional 3 ' cis-acting elF4E-regulatory proteins. $\boldsymbol{B}$, In 4E-BP2 knock-out mice, the basal levels of the elF4F complex are elevated, lowering the threshold for elicitation of L-LTP. L-LTP elicited by four $100 \mathrm{~Hz}$ trains is obstructed by excessive formation of the elF $4 \mathrm{~F}$ complex.

ability of pharmacological agents that inhibit general translation via peptide elongation to abrogate both L-LTP and memory formation. Interestingly, the disruption of a specific component of the translation regulatory machinery, $\mathrm{CPEB}$, was shown to confer TBS-induced LTP deficits in mice and long-term facilitation deficits in Aplysia (Si et al., 2003; Alarcon et al., 2004), but a role for $\mathrm{CPEB}$ in learning and memory has yet to be addressed. Our investigation offers the first evidence that the specific disruption of a cap-dependent translational regulator, 4E-BP2, and the subsequent deregulation of eIF4F complex formation results in dramatic LTP phenotypes and learning and memory deficits and provides a framework for a molecular understanding of the events that underlie activity-dependent translation initiation in the hippocampus (Fig. 9). Further investigation of the regulatory mechanisms that subserve activity-dependent translation may reveal the etiology of diseases and disorders that are associated with both altered protein synthesis and memory impairments, such as Alzheimer's disease and fragile X mental retardation.

\section{References}

Abel T, Nguyen PV, Barad M, Deuel TA, Kandel ER, Bourtchouladze R (1997) Genetic demonstration of a role for PKA in the late phase of LTP and in hippocampus-based long-term memory. Cell 88:615-626.

Alarcon JM, Hodgman R, Theis M, Huang YS, Kandel ER, Richter JD (2004) Selective modulation of some forms of Schaffer collateral-CA1 synaptic plasticity in mice with a disruption of the CPEB-1 gene. Learn Mem 11:318-327.
Atkins CM, Nozaki N, Shigeri Y, Soderling TR (2004) Cytoplasmic polyadenylation element binding protein-dependent protein synthesis is regulated by calcium/calmodulin-dependent protein kinase II. J Neurosci 24:5193-5201.

Banko JL, Hou L, Klann E (2004) NMDA receptor activation results in PKA- and ERKdependent Mnk1 activation and increased eIF4E phosphorylation in hippocampal area CA1. J Neurochem 91:462-470.

Barco A, Alarcon JM, Kandel ER (2002) Expression of constitutively active CREB protein facilitates the late phase of long-term potentiation by enhancing synaptic capture. Cell 108:689-703.

Beaumont V, Zhong N, Fletcher R, Froemke RC, Zucker RS (2001) Phosphorylation and local presynaptic protein synthesis in calcium- and calcineurin-dependent induction of crayfish long-term facilitation. Neuron 32:489-501.

Beretta L, Gingras AC, Svitkin YV, Hall MN, Sonenberg N (1996) Rapamycin blocks the phosphorylation of 4E-BP1 and inhibits capdependent initiation of translation. EMBO J 15:658-664.

Cao Q, Richter JD (2002) Dissolution of the maskin-eIF4E complex by cytoplasmic polyadenylation and poly(A)-binding protein controls cyclin B1 mRNA translation and oocyte maturation. EMBO J 21:3852-3862.

Casadio A, Martin KC, Giustetto M, Zhu H, Chen M, Bartsch D, Bailey CH, Kandel ER (1999) A transient, neuron-wide form of CREBmediated long-term facilitation can be stabilized at specific synapses by local protein synthesis. Cell 99:221-237.

Chen A, Muzzio IA, Malleret G, Bartsch D, Verbitsky M, Pavlidis P, Yonan AL, Vronskaya S, Grody MB, Cepeda I, Gilliam TC, Kandel ER (2003) Inducible enhancement of memory storage and synaptic plasticity in transgenic mice expressing an inhibitor of ATF4 (CREB-2) and C/EBP proteins. Neuron 39:655-669.

Dever TE (2002) Gene-specific regulation by general translation factors. Cell 108:545-556.

Fanselow MS (1984) Shock-induced analgesia on the formalin test: effects of shock severity, naloxone, hypophysectomy, and associative variables. Behav Neurosci 98:79-95.

Frey U, Morris RG (1997) Synaptic tagging and long-term potentiation. Nature 385:533-536.

Frey U, Morris RG (1998) Synaptic tagging: implications for late maintenance of hippocampal long-term potentiation. Trends Neurosci 21:181-188.

Frey U, Krug M, Reymann KG, Matthies H (1988) Anisomycin, an inhibitor of protein synthesis, blocks late phases of LTP phenomena in the hippocampal CA1 region in vitro. Brain Res 452:57-65.

Frey U, Frey S, Schollmeier F, Krug M (1996) Influence of actinomycin D, a RNA synthesis inhibitor, on long-term potentiation in rat hippocampal neurons in vivo and in vitro. J Physiol (Lond) 490:703-711.

Gingras AC, Sonenberg N (1997) Adenovirus infection inactivates the translational inhibitors 4E-BP1 and 4E-BP2. Virology 237:182-186.

Gingras AC, Kennedy SG, O’Leary MA, Sonenberg N, Hay N (1998) 4E$\mathrm{BP} 1$, a repressor of mRNA translation, is phosphorylated and inactivated by the Akt(PKB) signaling pathway. Genes Dev 12:502-513.

Gingras AC, Raught B, Sonenberg N (1999) eIF4 initiation factors: effectors of mRNA recruitment to ribosomes and regulators of translation. Annu Rev Biochem 68:913-963.

Haghighat A, Mader S, Pause A, Sonenberg N (1995) Repression of capdependent translation by $4 \mathrm{E}-$ binding protein 1 : competition with $\mathrm{p} 220$ for binding to eukaryotic initiation factor-4E. EMBO J 14:5701-5709.

Huang YY, Kandel ER (1994) Recruitment of long-lasting and protein ki- 
nase A-dependent long-term potentiation in the CA1 region of hippocampus requires repeated tetanization. Learn Mem 1:74-82.

Katz B, Miledi R (1968) The role of calcium in neuromuscular facilitation. J Physiol (Lond) 195:481-492.

Kelleher III RJ, Govindarajan A, Jung HY, Kang H, Tonegawa S (2004) Translational control by MAPK signaling in long-term synaptic plasticity and memory. Cell 116:467-479.

Li E, Bestor TH, Jaenisch R (1992) Targeted mutation of the DNA methyltransferase gene results in embryonic lethality. Cell 69:915-926.

Lin TA, Lawrence Jr JC (1996) Control of the translational regulators PHAS-I and PHAS-II by insulin and CAMP in 3T3-L1 adipocytes. J Biol Chem 271:30199-30204.

Mader S, Lee H, Pause A, Sonenberg N (1995) The translation initiation factor eIF-4E binds to a common motif shared by the translation factor eIF-4 gamma and the translational repressors 4E-binding proteins. Mol Cell Biol 15:4990-4997.

Markel P, Shu P, Ebeling C, Carlson GA, Nagle DL, Smutko JS, Moore KJ (1997) Theoretical and empirical issues for marker-assisted breeding of congenic mouse strains. Nat Genet 17:280-284.

Martin KC, Kosik KS (2002) Synaptic tagging-who's it? Nat Rev Neurosci $3: 813-820$

Martin KC, Casadio A, Zhu H, Yaping E, Rose JC, Chen M, Bailey CH, Kandel ER (1997) Synapse-specific, long-term facilitation of aplysia sensory to motor synapses: a function for local protein synthesis in memory storage. Cell 91:927-938.

Morris R (1984) Developments of a water-maze procedure for studying spatial learning in the rat. J Neurosci Methods 11:47-60.

Nguyen PV, Abel T, Kandel ER (1994) Requirement of a critical period of transcription for induction of a late phase of LTP. Science 265:1104-1107.

Niedzwiecka A, Marcotrigiano J, Stepinski J, Jankowska-Anyszka M, Wyslouch-Cieszynska A, Dadlez M, Gingras AC, Mak P, Darzynkiewicz E, Sonenberg N, Burley SK, Stolarski R (2002) Biophysical studies of eIF4E cap-binding protein: recognition of mRNA $5^{\prime}$ cap structure and synthetic fragments of eIF4G and 4E-BP1 proteins. J Mol Biol 319:615-635.

Pause A, Belsham GJ, Gingras AC, Donze O, Lin TA, Lawrence Jr JC, Sonenberg N (1994) Insulin-dependent stimulation of protein synthesis by phosphorylation of a regulator of $5^{\prime}$-cap function. Nature 371:762-767.

Phillips RG, LeDoux JE (1992) Differential contribution of amygdala and hippocampus to cued and contextual fear conditioning. Behav Neurosci 106:274-285.

Pineda VV, Athos JI, Wang H, Celver J, Ippolito D, Boulay G, Birnbaumer L, Storm DR (2004) Removal of G(ialpha1) constraints on adenylyl cyclase in the hippocampus enhances LTP and impairs memory formation. Neuron 41:153-163.

Poulin F, Gingras AC, Olsen H, Chevalier S, Sonenberg N (1998) 4E-BP3, a new member of the eukaryotic initiation factor 4E-binding protein family. J Biol Chem 273:14002-14007.

Poulin F, Brueschke A, Sonenberg N (2003) Gene fusion and overlapping reading frames in the mammalian genes for 4E-BP3 and MASK. J Biol Chem 278:52290-52297.

Schenk F, Morris RG (1985) Dissociation between components of spatial memory in rats after recovery from the effects of retrohippocampal lesions. Exp Brain Res 58:11-28.

Scheper GC, van Kollenburg B, Hu J, Luo Y, Goss DJ, Proud CG (2002) Phosphorylation of eukaryotic initiation factor $4 \mathrm{E}$ markedly reduces its affinity for capped mRNA. J Biol Chem 277:3303-3309.

Si K, Giustetto M, Etkin A, Hsu R, Janisiewicz AM, Miniaci MC, Kim JH, Zhu H, Kandel ER (2003) A neuronal isoform of CPEB regulates local protein synthesis and stabilizes synapse-specific long-term facilitation in aplysia. Cell 115:893-904.

Silva AJ (2003) Molecular and cellular cognitive studies of the role of synaptic plasticity in memory. J Neurobiol 54:224-237.

Stanton PK, Sarvey JM (1984) Blockade of long-term potentiation in rat hippocampal CA1 region by inhibitors of protein synthesis. J Neurosci 4:3080-3088.

Stebbins-Boaz B, Cao Q, de Moor CH, Mendez R, Richter JD (1999) Maskin is a CPEB-associated factor that transiently interacts with elF-4E. Mol Cell 4:1017-1027.

Tang SJ, Reis G, Kang H, Gingras AC, Sonenberg N, Schuman EM (2002) A rapamycin-sensitive signaling pathway contributes to long-term synaptic plasticity in the hippocampus. Proc Natl Acad Sci USA 99:467-472.

Tsukiyama-Kohara K, Vidal SM, Gingras AC, Glover TW, Hanash SM, Heng H, Sonenberg N (1996) Tissue distribution, genomic structure, and chromosome mapping of mouse and human eukaryotic initiation factor 4E-binding proteins 1 and 2. Genomics 38:353-363.

Tsukiyama-Kohara K, Poulin F, Kohara M, DeMaria CT, Cheng A, Wu Z, Gingras AC, Katsume A, Elchebly M, Spiegelman BM, Harper ME, Tremblay ML, Sonenberg N (2001) Adipose tissue reduction in mice lacking the translational inhibitor 4E-BP1. Nat Med 7:1128-1132.

Wang X, Flynn A, Waskiewicz AJ, Webb BL, Vries RG, Baines IA, Cooper JA, Proud CG (1998) The phosphorylation of eukaryotic initiation factor eIF4E in response to phorbol esters, cell stresses, and cytokines is mediated by distinct MAP kinase pathways. J Biol Chem 273:9373-9377.

Waskiewicz AJ, Johnson JC, Penn B, Mahalingam M, Kimball SR, Cooper JA (1999) Phosphorylation of the cap-binding protein eukaryotic translation initiation factor $4 \mathrm{E}$ by protein kinase Mnk1 in vivo. Mol Cell Biol 19:1871-1880.

You-Ten KE, Muise ES, Itie A, Michaliszyn E, Wagner J, Jothy S, Lapp WS, Tremblay ML (1997) Impaired bone marrow microenvironment and immune function in T cell protein tyrosine phosphatase-deficient mice. J Exp Med 186:683-693.

Zuberek J, Wyslouch-Cieszynska A, Niedzwiecka A, Dadlez M, Stepinski J, Augustyniak W, Gingras AC, Zhang Z, Burley SK, Sonenberg N, Stolarski R, Darzynkiewicz E (2003) Phosphorylation of eIF4E attenuates its interaction with mRNA $5^{\prime}$ cap analogs by electrostatic repulsion: inteinmediated protein ligation strategy to obtain phosphorylated protein. RNA 9:52-61.

Zuberek J, Jemielity J, Jablonowska A, Stepinski J, Dadlez M, Stolarski R, Darzynkiewicz E (2004) Influence of electric charge variation at residues 209 and 159 on the interaction of eIF4E with the mRNA $5^{\prime}$ terminus. Biochemistry 43:5370-5379. 